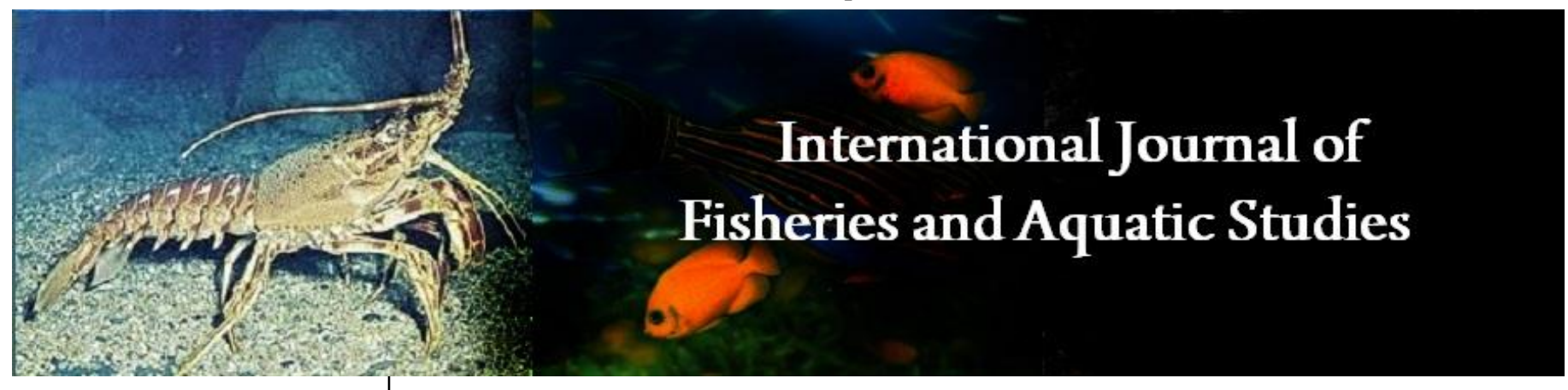

E-ISSN: 2347-5129

P-ISSN: 2394-0506

(ICV-Poland) Impact Value: 5.62

(GIF) Impact Factor: 0.549

IJFAS 2020; 8(6): 24-30

(C) 2020 IJFAS

www.fisheriesjournal.com

Received: 16-09-2020

Accepted: 20-10-2020

Marco F De Guzman

Aurora State College of

Technology, Casiguran, Aurora,

Philippines

Rhea Lyn S Macalalay

Aurora State College of

Technology, Casiguran, Aurora,

Philippines

Rose Angela F Surat

Aurora State College of

Technology, Casiguran, Aurora,

Philippines

Joseph B Villaruz

Aurora State College of

Technology, Casiguran, Aurora,

Philippines

Geronimo R Rosario

Pangasinan State University-

Binmaley Campus, Binmaley,

Pangasinan, Philippines

\section{Catch composition and relative biomass of fishes caught by danish seine in Lingayen gulf}

\author{
Marco F De Guzman, Rhea Lyn S Macalalay, Rose Angela F Surat, \\ Joseph B Villaruz and Geronimo R Rosario
}

DOI: https://doi.org/10.22271/fish.2020.v8.i6a.2355

\section{Abstract}

The Lingayen Gulf is one of the major fishing grounds in the Philippines. The main clients of the fishing ground are the fishermen in the province of Pangasinan. The bulk of the catch of these fishermen are caught mainly using Danish Seine. Though there have been study conducted, related or succeeding studies were not undertaken so far. In the absence of updated studies, we undertaken a study to assess the catch composition and relative biomass of fishes caught by Danish seine. Two Sampling sites were selected, namely, Sector I (western Coast) and Sector III (eastern Coast). Two 45 HP commercial fishing vessels were utilized in the study in two sectors of the Gulf. Each vessel utilized modified Danish seine net and sampling was done every 15 days for a period of two months. The landed catch volume of every species were obtained from the fishing vessel's logbook. Results showed that there were 38 species of finfishes belonging to 22 families identified in the two sectors $(25$ species in Sector I and 29 species in Sector III). Decapterus macrosoma yielded the highest catch for the whole sampling periods and the most dominant catch in Sector I, while Saurida tumbil in Sector III. Catch landings were higher in Sector I with $6,448.6 \mathrm{~kg}$ as compared to Sector III has $2,525.8 \mathrm{~kg}$. Out of the 22 families identified, 14 of these were demersal while the remaining were pelagic. Two new families were identified in this study which not mentioned in the early studies. Due to the limitations of this study, further studies related on the growth by sexes and other important growth parameters of different species is recommended for better management of the Lingayen Gulf.

Keywords: Sectors one and three, global positioning system, fishing vessel and danish seine

\section{Introduction}

Lingayen Gulf is one of the primary sources of livelihood of the people particularly those living in the coastal areas. There are about 1.2 million people as of 2010 census residing in the 15 towns and three cities located along the gulf translating about $34 \%$ of the total population in the province of Pangasinan and La Union ${ }^{[1]}$. The gulf also serves as the major fishing ground for both the commercial and municipal fishermen. However, data on the catch volume in Lingayen Gulf, is scarce and very limited. Earlier reports disclosed that the total catch of local fishermen (16,000 municipal fishermen and 80 commercial fishermen) in the gulf was about $6,500 \mathrm{MT}$ in $2001^{[2]}$. The distribution of municipal fishermen by sector varied, where Sector I has the highest percentage with $47 \%$, Sector II with $30 \%$ and Sector III with $23 \%$. In addition, most of the commercial fishermen are based in Dagupan City, Sual and Mangaldan ${ }^{[3]}$.

Based on the various reports, there are 32 different types of fishing gears used in the gulf ${ }^{[4-10]}$. In the commercial fisheries sector, Danish seines and Trawls are the commonly operated fishing gears with a total catch of 9,653.52 metric tons (MT) from 1998-2002, and which 65\% are accounted in Danish seines ${ }^{[11]}$.

In April 1988, Danish seine fishing was introduced in the gulf from Samar Sea and started its operation with three boats ${ }^{[12]}$. On the latest inventory conducted by BFAR in 2002 it shows that there are 41 registered Danish seine fishing boats operating and it also have a catch per unit of effort (CPUE) measured at kg/boat/day range from $91.78 \mathrm{~kg} / \mathrm{b} / \mathrm{d}$ to $116.11 \mathrm{~kg} / \mathrm{b} / \mathrm{d}^{[11]}$. However, it was found out that it contributes to the destruction of marine habitats and fishery resources which violates section 92 of Republic Act 8550, also known as the Fisheries Code of the Philippines ${ }^{[13]}$.

Though the study of ${ }^{[11]}$ was conducted for five years (1997-2002) covering all the fishing gears in the area including Danish seine, related or succeeding studies were not undertaken so
Corresponding Author: Aurora State College of Technology, Casiguran, Aurora, Philippines 
far and there is still limited researches and publications on the catch composition of Danish seine operating in the gulf.

It is indispensable to have an inventory on the catch composition of fishes caught by Danish seine in the Sectors I and III of Lingayen Gulf and it is timely as it provides updates and information of Danish seine fisheries in the Gulf. Furthermore, the outcome of this study may also use in support on the banning of the gear (Danish seine and modified Danish seine) in the Philippine Waters under the Fisheries Administrative Order (FAO) No. 246 for the better fisheries management of the gulf particularly on integrated coastal resource management program of the government.

\section{Materials and Methods \\ Research Method and Design}

This study employed a descriptive-survey method of research. Every 15 days, catch landings of Danish seines from Sectors I and III in Lingayen Gulf were monitored and recorded. The species composition and volume of catches were determined for every landing.

\section{Location of the Study}

Lingayen Gulf is one of the major fishing grounds of the
Philippines located in the northwestern part of Luzon. It lies within $16^{\circ} 00^{\prime} \mathrm{N}$ and $16^{\circ} 40^{\prime} \mathrm{N}$ latitudes and $119^{\circ} 55^{\prime} \mathrm{E}$ and $120^{\circ} 25^{\prime}$ E longitudes. It is bounded on the west and south of Pangasinan province and northeast by $\mathrm{La}$ Union province. The gulf covers a total area of $2,085 \mathrm{~km}^{2}$ with a $160 \mathrm{~km}$ coastline from Cape Bolinao to Poro Point and generally shallow with depths of less than $90 \mathrm{~m}^{\text {[14]. }}$

The Gulf has been classified into three sectors according to dominant coastal features ${ }^{[15]}$. Based on the bottom types of the gulf, Mines (1986) subdivided it into three sectors, namely; Sector I- (western coast) - which extends from Cape Bolinao to Sual and characterizes by coral reefs and seagrass beds; Sector II- (inner coast)- extends from Sual to Damortis and have a muddy substrate, mangroves and nipa swamps where aquaculture activities are concentrated and Sector III (eastern coast)-characterized by sandy bottom with scattered rocky substrate.

The study was conducted in the Magsaysay Market, Dagupan City, Pangasinan where the Danish seines operators landed their catch. Danish seine operators served as cooperators and the sources of samples. Two Danish seine vessels were operated in the two sectors; one each in Sector I and Sector III.

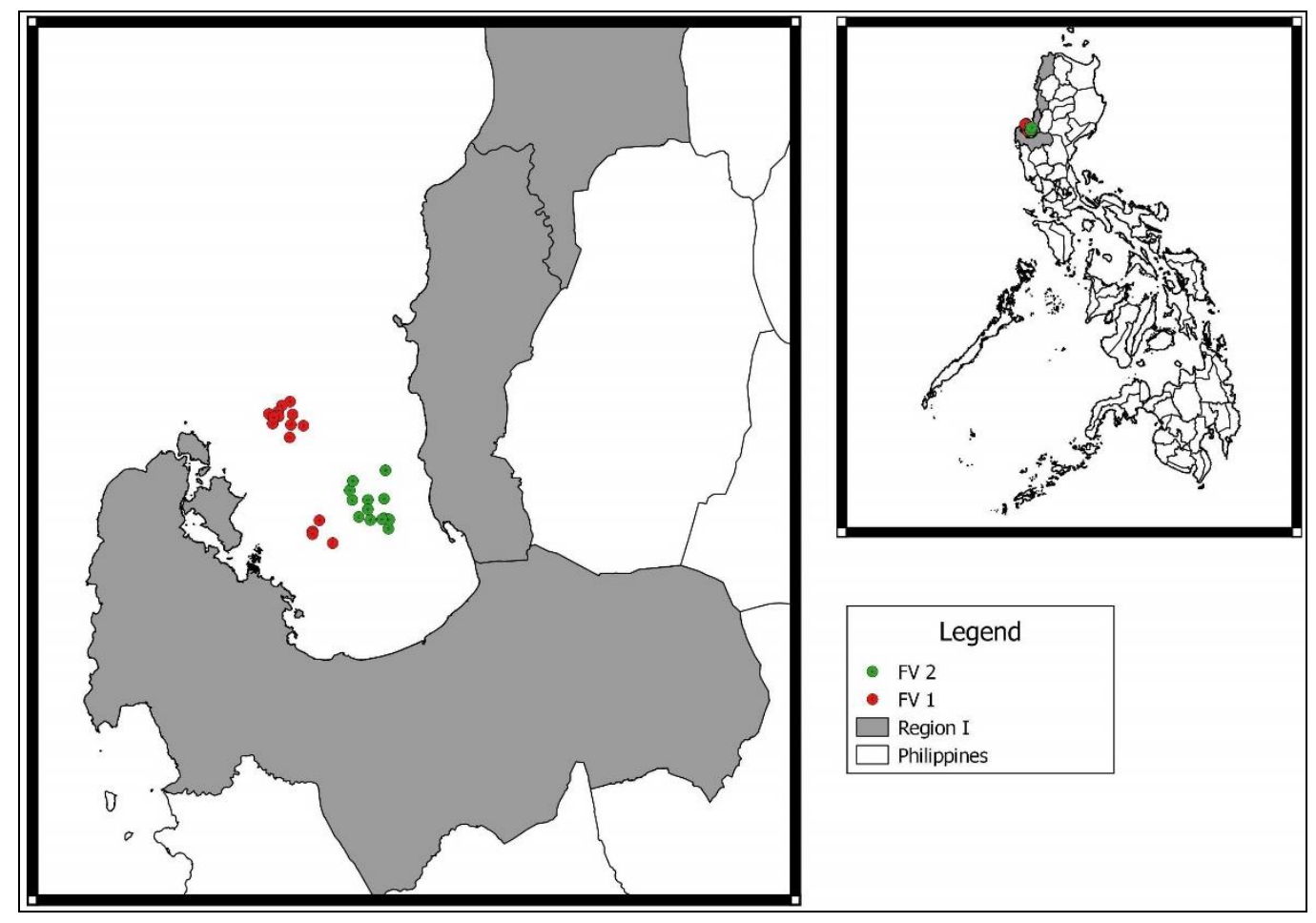

Fig 1: Map showing the fishing areas of Danish seine fishing vessels in Lingayen Gulf.

\section{Fishing Vessel and Fishing Operation}

Sampling was undertaken using two Danish seine fishing vessels. The fishing vessels had an overall length of $14.02 \mathrm{~m}$, $3 \mathrm{~m}$ breadth and $3 \mathrm{~m}$ a depth. Both fishing vessels were also powered with $45 \mathrm{hp}$ engine and equipped with navigational instruments such as Global Positioning System (GPS) receivers, magnetic compass, Fish Finder and VHF radio receiver. Each fishing vessel carried an AM/FM band radio to monitor the weather condition through listening to programs that broadcasting weather reports. Each vessel utilized modified Danish seine net measuring $180 \mathrm{~m}$. It also had a scare line (tingga and cut of sacks) of $120 \mathrm{~m}$ on each side, a wing of $60 \mathrm{~m}$ on each side and a pouch bag of $25 \mathrm{~m}$ with a mesh size (\#12, \#9 and \#6) towards the cod end.
The whole operation takes about 1-11/2 hours. The catch is iced down quickly to ensure a quality product.

\section{Sampling and Data Gathering}

Sampling was done every 15 days from December 2015 to January 2016. The volume $(\mathrm{kg})$ of catch landed by species were obtained from the fishing vessel's logbook. To determine the species composition, a specimen for each species was collected from the master fisherman in the Magsaysay Market, Dagupan City. The species were identified through their morphological features based on the books of $[16,17]$ and verified using Fish Base for proper identification. Unidentified species were preserved using ethanol in a glass container and brought to Pangasinan State 
University, Binmaley Campus (PSU-BC) Wet Laboratory for further identification.

In terms of the relative biomass (RB) by species, the following formula was used:

$\mathrm{RB}=(\mathrm{V} / \mathrm{TV}) \mathrm{X} 100$

where:

$\mathrm{V}=$ volume of catch of each species

$\mathrm{TV}=$ total volume of catch

\section{Results}

\section{Species Composition}

A total of 38 species of finfishes belonged to 22 families were captured by Danish seine operated in the Sectors I and III of Lingayen Gulf from December 2015 to January 2016 (Table 1). Based on the landed catch, Sector I had 25 species while Sector III recorded 29 species.
In Sector I, Family Carangidae obtained the highest number of species, with 7 out of 25 species which made up $28 \%$ (Table 2). This was followed by Family Leiognathidae that comprised $12 \%$ and the Family Scombridae and Serranidae both consisted $8 \%$. The rest of the families caught include Lethrinidae, Lutjanidae, Malacanthidae, Menidae, Monocantidae, Mullidae, Nemipteridae, Priancantidae, Sphyraenidae, Synodontidae, and Trichiuridae which were accounted $4 \%$ of landed catch.

In Sector III, Family Carangidae also dominated the catch with a $20.7 \%$. Species under families Paralichthyidae and Scombridae had an $6.89 \%$ each, while the families Nemipteridae, Sphyraenidae, Mullidae, Synodontidae, Malacanthidae, Trichiuridae, Lethrinidae, Menidae, Lutjanidae, Gerreidae, Terapontidae, Leiognatidae, Ambassidae, Congridae, Serranidae and Chirocentridae had $3.45 \%$ each.

Table 1: Species composition of finfishes caught by Danish Seine in Sectors I and III of Lingayen Gulf from December 2015 to January 2016. (Note: positive (+) sign means present in the catch; negative (-) sign means absent in the catch).

\begin{tabular}{|c|c|c|c|}
\hline Family & Scientific Name & Sector I & Sector III \\
\hline Ambassidae & Ambassis miops & - & + \\
\hline \multirow{10}{*}{ Carangidae } & Alectis ciliaris & + & + \\
\hline & Alectis indica & - & + \\
\hline & Atule mate & + & + \\
\hline & Carangoides coeruleopinnatus & - & + \\
\hline & Caranx ignobilis & + & + \\
\hline & Decapterus kurroides & + & - \\
\hline & Decapterus macrosoma & + & - \\
\hline & Selar crumenophthalmus & + & + \\
\hline & Selaroides leptolepis & - & + \\
\hline & Uraspis uraspis & + & - \\
\hline Chirocentridae & Chirocentrus nudus & - & + \\
\hline Congridae & Conger cinereus & - & + \\
\hline Gerreidae & Gerres filamentosus & - & + \\
\hline \multirow{3}{*}{ Leiognathidae } & Photopectoralis aureus & + & - \\
\hline & Leiognathus equulus & + & + \\
\hline & Aurigequula fasciata & + & - \\
\hline Lethrinidae & Gymnocranius griseus & + & + \\
\hline Lutjanidae & Lutjanus russellii & + & + \\
\hline Malacanthidae & Branchiostegus japonicus & + & + \\
\hline Menidae & Mene maculata & + & + \\
\hline Monacanthidae & Aluterus monoceros & + & - \\
\hline \multirow{2}{*}{ Mullidae } & Upeneus moluccensis & - & + \\
\hline & Mulloidichthys pfluegeri & + & - \\
\hline Nemipteridae & Nemipterus bathybius & + & + \\
\hline \multirow{2}{*}{ Paralichthyidae } & Pseudorhombus dupliciocellatus & - & + \\
\hline & Pseudorhombus cinnamoneus & - & + \\
\hline \multirow{2}{*}{ Priacanthidae } & Priacanthus tayenus & + & + \\
\hline & Pristigenys niphonia & - & + \\
\hline \multirow{3}{*}{ Scombridae } & Scomberomorus commerson & + & - \\
\hline & Rastrelliger kanagurta & + & + \\
\hline & Rastrelliger brachysoma & - & + \\
\hline \multirow{2}{*}{ Serranidae } & Epinephelus sexfasciatus & + & + \\
\hline & Epinephelus coioides & + & - \\
\hline Sphyraenidae & Sphyraena barracuda & + & + \\
\hline Synodontidae & Saurida tumbil & + & + \\
\hline Terapontidae & Terapon jarbua & - & + \\
\hline \multirow[t]{2}{*}{ Trichiuridae } & Trichiurus lepturus & + & + \\
\hline & Total & 25 & 29 \\
\hline
\end{tabular}

\section{Relative Biomass}

The total landed catch by Danish seine from Sectors I and III of Lingayen Gulf from December 2015 to January 2016 was
$8,974.4 \mathrm{~kg}$ (Table 2). Sector I as the higher catch landings of $6,448.6 \mathrm{~kg}(71.9 \%)$ as compared to Sector III with $2,525.8 \mathrm{~kg}$ $(28.1 \%)$ 
Table 2: Biomass $(\mathrm{kg})$ of species caught by Danish Seine in Sectors I and III of Lingayen Gulf, Pangasinan from December 2015 to January 2016.

\begin{tabular}{|c|c|c|c|c|}
\hline Family & Scientific Name & $\begin{array}{c}\text { Sector } \\
\text { I (kg) }\end{array}$ & $\begin{array}{c}\text { Sector } \\
\text { III (kg) }\end{array}$ & $\begin{array}{l}\text { Total } \\
(\mathrm{kg})\end{array}$ \\
\hline Ambassidae & Ambassis miops & - & 0.3 & 0.3 \\
\hline \multirow{10}{*}{ Carangidae } & Alectis ciliaris & 0.1 & 0.15 & 0.25 \\
\hline & Alectis indica & - & 0.1 & 0.1 \\
\hline & Atule mate & 99.9 & 16.5 & 116.4 \\
\hline & Carangoides coeruleopinnatus & - & 0.3 & 0.3 \\
\hline & Caranx ignobilis & 0.7 & 0.4 & 1.1 \\
\hline & Decapterus kurroides & 594.0 & - & 594 \\
\hline & Decapterus macrosoma & $2,416.2$ & - & 2416.2 \\
\hline & Selar crumenophthalmus & 314.0 & 8.5 & 322.5 \\
\hline & Selaroides leptolepis & - & 1.3 & 1.3 \\
\hline & Uraspis uraspis & 0.3 & - & 0.3 \\
\hline Chirocentridae & Chirocentrus nudus & - & 46.5 & 46.5 \\
\hline Congridae & Conger cinereus & - & 15.5 & 15.5 \\
\hline Gerreidae & Gerres filamentosus & - & 0.9 & 0.9 \\
\hline \multirow{3}{*}{ Leiognathidae } & Photopectoralis aureus & 0.15 & - & 0.15 \\
\hline & Leiognathus equulus & 34.8 & 1.3 & 36.1 \\
\hline & Aurigequula fasciata & 0.1 & - & 0.1 \\
\hline Lethrinidae & Gymnocranius griseus & 0.5 & 0.5 & 1.0 \\
\hline Lutjanidae & Lutjanus russellii & 0.6 & 0.8 & 1.4 \\
\hline Malacanthidae & Branchiostegus japonicus & 18.5 & 2 & 20.5 \\
\hline Menidae & Mene maculata & 0.25 & 0.7 & 0.95 \\
\hline Monacanthidae & Aluterus monoceros & 1.1 & - & 1.1 \\
\hline \multirow{2}{*}{ Mullidae } & Upeneus moluccensis & - & 165 & 165 \\
\hline & Mulloidichthys pfluegeri & 38.6 & - & 38.6 \\
\hline Nemipteridae & Nemipterus bathybius & 561.0 & 240.5 & 801.5 \\
\hline \multirow{2}{*}{ Paralichthyidae } & Pseudorhombus dupliciocellatus & - & 0.5 & 0.5 \\
\hline & Pseudorhombus cinnamoneus & - & 0.1 & 0.1 \\
\hline \multirow{2}{*}{ Priacanthidae } & Priacanthus tayenus & 215.0 & 69.3 & 284.3 \\
\hline & Pristigenys niphonia & - & 0.15 & 0.15 \\
\hline \multirow{3}{*}{ Scombridae } & Scomberomorus commerson & 32.0 & - & 32 \\
\hline & Rastrelliger kanagurta & 599.0 & 59 & 658 \\
\hline & Rastrelliger brachysoma & - & 561 & 561 \\
\hline \multirow{2}{*}{ Serranidae } & Epinephelus sexfasciatus & 0.3 & 1.8 & 2.1 \\
\hline & Epinephelus coioides & 30.5 & - & 30.5 \\
\hline Sphyraenidae & Sphyraena barracuda & 956.0 & 178 & 1134.0 \\
\hline Synodontidae & Saurida tumbil & 494.5 & 792 & 1286.5 \\
\hline Terapontidae & Terapon jarbua & - & 1.7 & 1.7 \\
\hline \multirow[t]{2}{*}{ Trichiuridae } & Trichiurus lepturus & 40.5 & 361 & 401.5 \\
\hline & Total & $6,448.6$ & $2,525.8$ & $8,974.4$ \\
\hline
\end{tabular}

Looking at the relative biomass of species in Sector I (Figure 2), Decapterus macrosoma was the most captured species with $37.5 \%$ of the total landed catch from December 2015 to January 2016. This was followed by Sphyraena barracuda (14.8\%), Rastrelliger kanagurta (9.3\%), Decapterus kurroides (9.2\%), Nemipterus bathybius (8.7\%), Saurida tumbil $(7.7 \%)$, Selar crumenophthalmus (4.9\%), Atule mate (1.5\%), Trichiurus lepturus (0.6\%), Mulloidichthys pfluegeri $(0.6 \%)$ and the other landed catch accumulated 5.2\%.

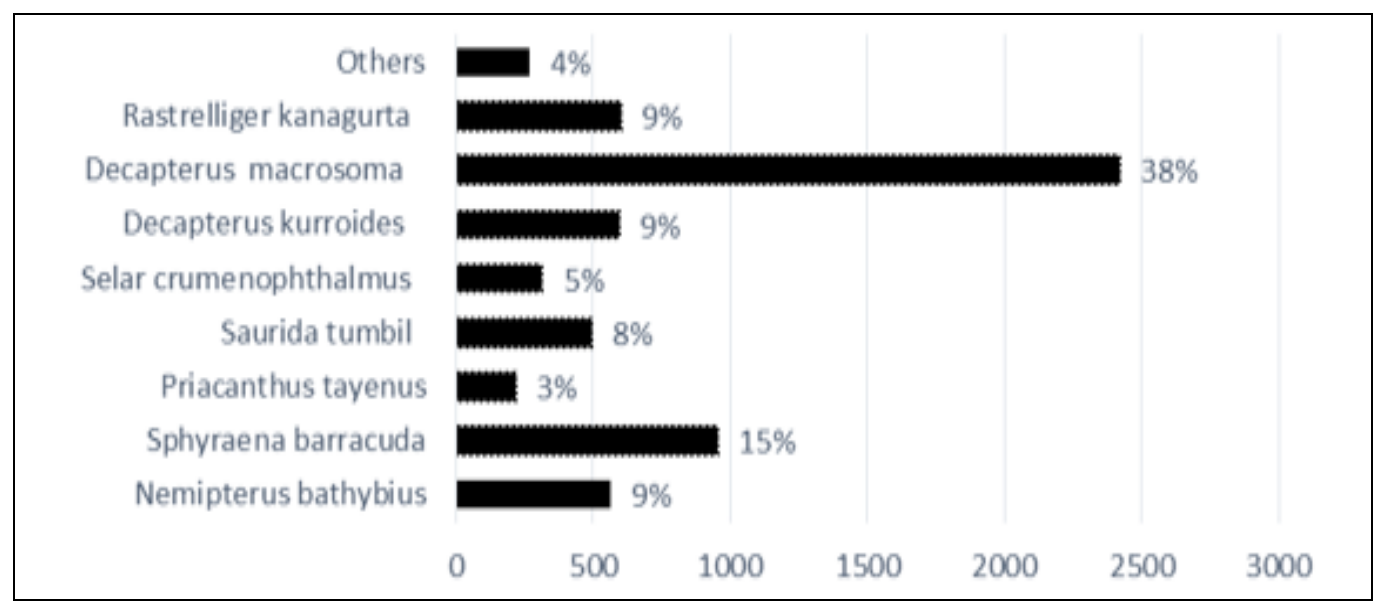




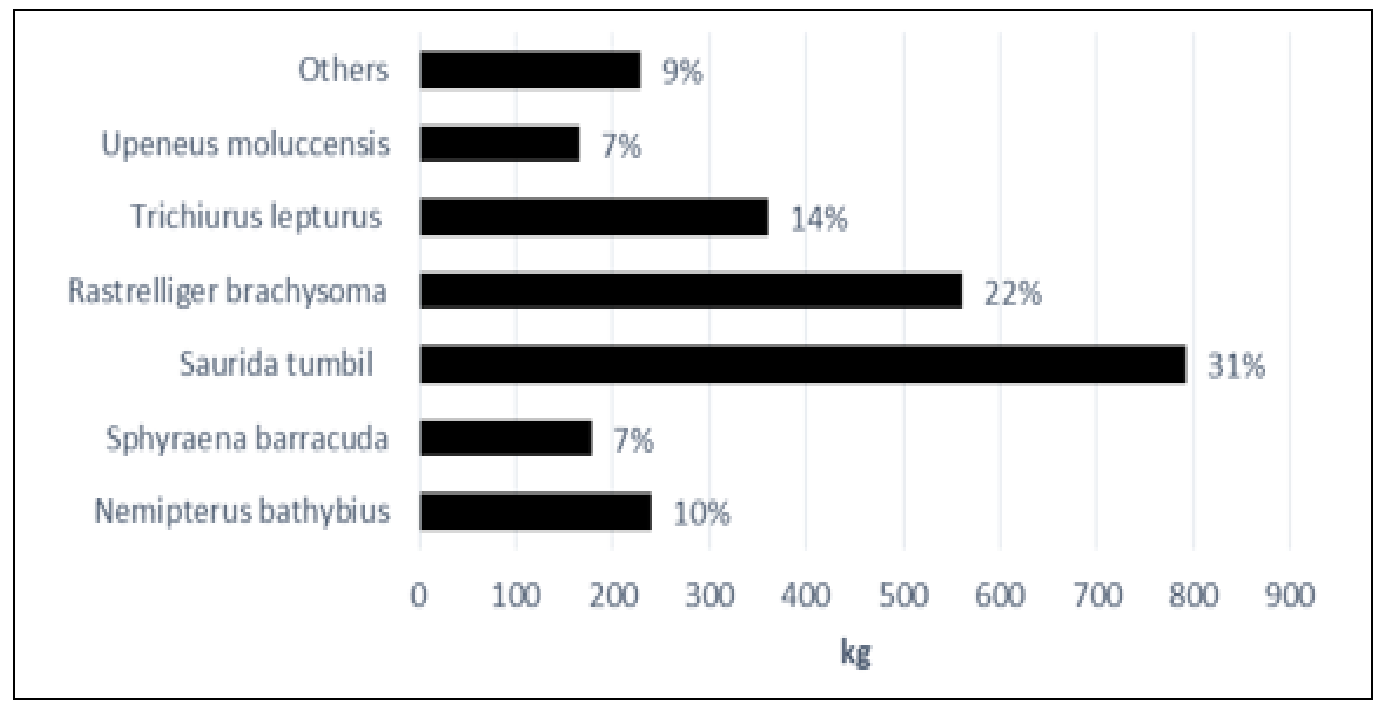

Fig 2: Relative biomass (\%) of species caught by Danish Seine in Sector I (top) and Sector III (bottom) of Lingayen Gulf, Pangasinan from December 2015 to January 2016.

The aggregated relative biomass of species caught by Danish seine in both Sectors I and III are presented in Figure 3. Of the total landed catch from December 2015 to January 2016,
Decapterus macrosoma dominated the catch with $27 \%$, while the lowest species caught was the Atule mate with only $1 \%$ of overall catch in two Sectors.

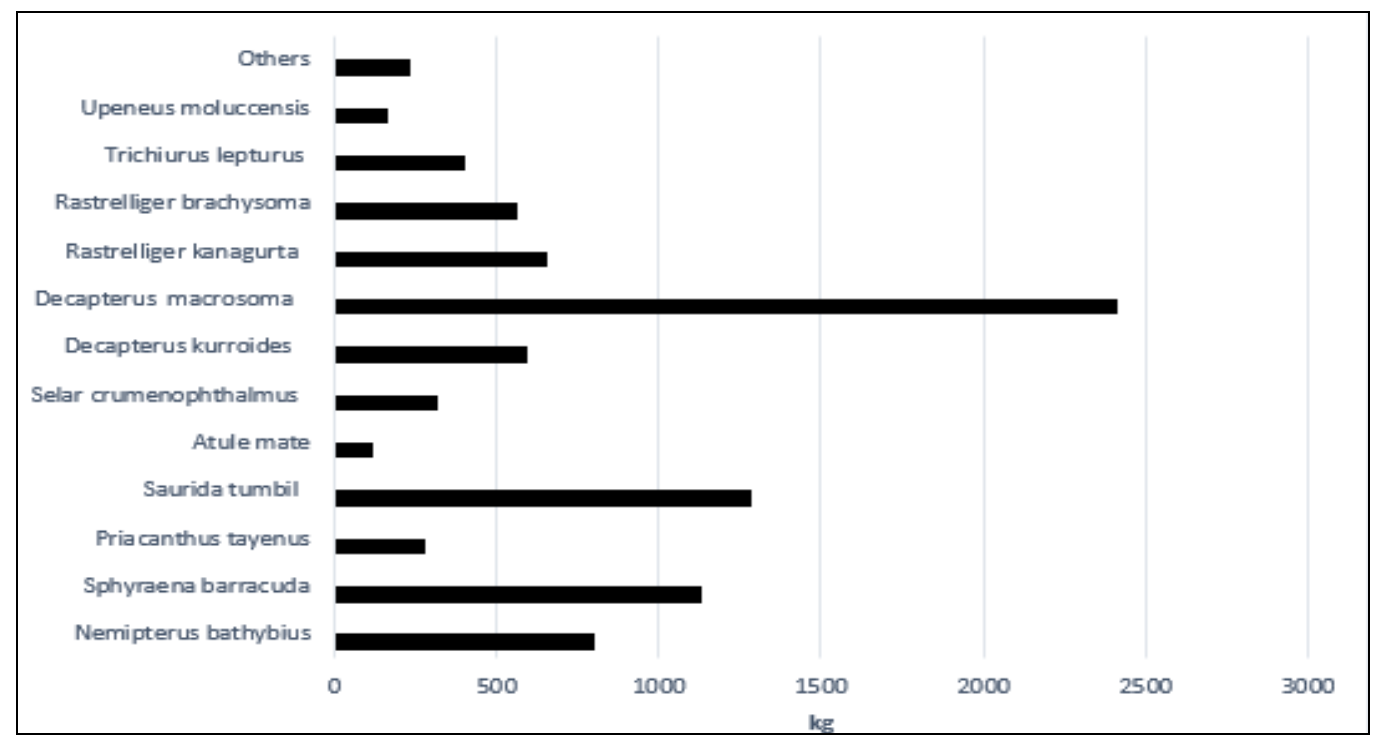

Fig 3: Combined relative biomass (\%) of species caught by Danish Seine in Sector I and III in Lingayen Gulf, Pangasinan from December 2015 to January 2016.

\section{Discussion}

Danish seine fishery is one of the major fisheries in Lingayen Gulf that provides food supply, income and livelihood to several coastal communities. Round scads, which are locally known as "galunggong", are among the important small pelagic fishes caught in municipal and commercial fisheries in large quantities in the Philippine water throughout the year ${ }^{[18,}$ 19]. The results of this study indicates that there are two species of round scads present in Lingayen Gulf, and these were D. macrosoma and D. kurroides. Furthermore, $D$. macrosoma dominated the catch and was abundant in January which is contrary to the early findings of ${ }^{[11]}$ which the peak months of D. macrosoma in their study were seen during the July to December. The different results may be attributed to the occurrence of typhoon" Nona" in December, 2015 that traversed through the Lingayen Gulf.

However, there are several findings that indicate different spawning seasons of D. macrosoma. Based on the results of
[20] in Mozambique, the spawning seasons of this species is from December to February and June to September while the findings of ${ }^{[21]}$ with the used of Gonadosomatic Index (GSI) in Romblon shows that the peaks of the spawning of $D$. macrosoma are in February, August and October. It was also reported in the study of ${ }^{[22]}$ that the peak of spawning of this species was from February to April while ${ }^{[23]}$ stated that the fish spawned between February and March. Presence of this species in these months maybe attributed to their spawning patterns. However, other parameters should still be considered to help support the findings and have baseline information for better management of the gulf.

Of the 21 families identified, $14(66.67 \%)$ of these are demersal namely; Mullidae, Monacanthidae, Malacanthidae, Teraponthidae, Menidae, Congridae, Chirocentridae, Nemipteridae, Synodonthidae, Carangidae, Scombridae, Leiognathidae, and Paralicthyidae while the remaining $33.33 \%$ are pelagic species are the families of Trichiuridae, 
Lethrinadae, Ambsssidae, Lutjanidae, Sphyraenidae, Serranidae, and Menidae. Based on the results found, most species caught by the Danish seine on Sectors I and III in the Lingayen Gulf are demersal.

This study also indicates that the operation of Danish Seine in some areas of the Gulf still continues even though that BFAR Central Office issued Fisheries Administrative Order (FAO) 246 in 2013, which ban the operation of Danish Seine and Modified Danish Seine in the Philippine waters. The rampant illegal fishing in the Lingayen Gulf might cause environment degradation. In addition, further studies related on the growth by sexes and other important growth parameters of different species is recommended for better management of the Lingayen Gulf.

\section{Conclusion}

1. There are 25 fish species belonging to 15 families in the Danish Seine of Sector I and 29 species belonging to 20 families in the Danish seine of Sector III.

2. Decapterus macrosoma, has obtained the highest on the total catch biomass of the Sectors I and III of the Lingayen Gulf catch by the Danish seine.

3. The species caught are dominated by demersal species.

\section{Recommendations}

1. Conduct another study covering the fish caught of all the major Fishing gear use in the Sectors I and III of Lingayen Gulf to ensure the better management of the Gulf particularly on integrated coastal resource management program of the government.

2. Link with other Municipal and City Government in the conduct of similar study to generate information on the present status of the Gulf.

\section{References}

1. PSA (Philippine Statistics Authority). 2015. Fisheries Statistics. Quezon City, Philippines. https://psa.gov.ph. Accessed on 10 September 2019.

2. Hilomen VV, Licuanan W, Alino P, Jimenez L. Status of the fisheries resources in Lingayen Gulf: erasing the pressure and enhancing the resources. Paper presented at the National Conference on Fisheries Resource and Social Assessments, Development Academy of the Philippines, Tagaytay City. Fisheries Resource Management Project, Department of Agriculture, Quezon City, Philippines 2002.

3. Hilomen VV, Jimenez LF. Status of Fisheries in Lingayen Gulf (Appendix 1). In: McGlone $M$ and Villanoy C (eds). Resource and Social Assessment of Lingayen Gulf. Project Report submitted to the Fisheries Resource Management Project, Department of Agriculture. Marine Environment and Resource Foundation, Quezon City, Philippines 2001.

4. Umali AF. Guide to the Classification of Fishing Gear in the Philippines. Fish and Wildlife Service, United States Department of the Interior, Washington, D.C. Research Report 1950;17:165.

5. Lucas RM. Some Fishing methods of Lingayen Gulf. Undergraduate thesis. Philippine Institute of Fisheries Technology Manila 1952, 28.

6. Cefre BC. Some of methods of fish capture in Bolinao, Pangasinan. Undergraduate thesis. Philippine Institute of Fisheries Technology, Port Area, Manila 1953, 40.

7. Bailen JB. Blast fishing in Lucap. Department of
Anthropology, University of the Philippines 1978, 36.

8. NCSO (National Census and Statistics Office). The 1980 census of fisheries. National summary, National Census and Statistics Office and National Economic Development Authority, Manila 1980, 1.

9. Kitamado T. Report on the construction of an artificial reef in Lingayen Gulf, Luzon Island, Philippines. Japan Overseas Cooperation Volunteers, Hyogo, Japan 1984, 142.

10. Mines A. An Assessment of the fisheries of Lingayen Gulf. College of Fisheries, University of the Philippines in the Visayas, Diliman, Quezon City. PCARRD/NSTA Project Report. 1986, 26.

11. Gaerlan RSP, Barut NC, Buccat FGA, Bugaoan BC. An assessment of the Lingayen Gulf Fisheries, Philippines. Bureau of Fisheries and Aquatic Resources Region I. ssme 2002. iwlearn.org/publications/resources/referencematerials. Accessed on 20 October 2019.

12. Ochavillo D, Silvestre GT. Optimum Mesh Size for the Trawl Fisheries of Lingayen Gulf, Philippines. In: Chuo LM, Chua TE, Khoo HW, Lim PE, Paw JN, Silvestre GT, Valencia MJ, White AT and Wong PK (eds). Towards an Integrated management of tropical coastal resources. ICLARM Conference Proceedings 1991;22:41-44.

13. Silvestre GT, Hilomen VV. Status of Lingayen Gulf fisheries-a brief update. In: Department of AgricultureBureau of Fisheries and Aquatic Resources. In turbulent seas: The status of the Philippine Marine Fisheries. Coastal Resource Management Project, Cebu City, Philippines 2004, 285-291.

14. Galvez R, Higco TG, Bautista C, Tungpalan MT. Sociocultural dynamics of blast fishing and sodium cyanide fishing in two fishing villages in the Lingayen Gulf area, p. 43-62. In G. Silvestre, E. Miclat and T.E. Chua (eds.) Towards sustainable development of the coastal resources of Lingayen Gulf, Philippines. ICLARM Conference Proceedings 1989;17:200.

15. Mcmanus LT, Chua TE. The coastal environmental profile of Lingayen Gulf, Philippines. International Center for Living Aquatic Resources Management. Technical Report 1990, 69.

16. Conlu PV. A Guide to Philippine flora and fauna. Fishes. Natural Resources Management Center, Quezon City. 1986;9:495.

17. Rau N, Rau A. Commercial Marine Fishes of Central Philippines. German Agency for Technical Cooperation 1980, 623.

18. Calvelo RR. Synopsis of biological and related data on Philippine roundscads. Philippine Journal of Fisheries 1992, 51-80.

19. Pastoral PC, Severino Jr. EL, Lamarca NJ. Round scad exploration by purse seine in the South China Sea, Area III: Western Philippines. Proceedings of the SEAFDEC Seminar on Fishery Resources in the South China Sea, Area III: Western Philippines 2000.

20. Sousa MI, Gjøsaeter J. Reproduction, age, and growth of Round Scad (Decapterus macrosoma) Blecker 1851, Caragidae from Mozambique. Revista de Investigacao Pesqueira Maputo 1987;16:1-17.

21. Rada BG, Ramos EB, Riva CJ, Royo NR. Preliminary Study on Spawning Period and Length at Maturity of Shortfin Scad, Decapterus macrosoma, (Bleeker, 1851, 
Perciformes:Carangidae) from the Coastal Waters of San Fernando, Romblon. Philippine Journal of Fisheries 2019, 35-43

22. Senen B, Sulistiono, Muchsin dI. Aspek biologi ilan Layang Deles (Decapterus macrosoma) di perairan Band Neira,Maluku. Jurnal Pertanian-UMMI 2011;1(1):34-40.

23. Shiraishi T, Tanaka H, Ohshimo S, Ishida H, Morinaga N. Age, growth and reproduction of two species of Sscad, Decapterus macrosoma and D. macarellus in the Waters off Southern Kyushu. JARQ 2010;44(2):197-206. 